\title{
GENETIC MARKERS OF RESISTANCE TO LEPTOSPIROSIS IN PIGS OF THE LARGE WHITE POLISH BREED
}

\author{
T. PRZYTULSKI and D. PORZECZKOWSKA
}

Institute of Animal Breeding and Technology of Animal Production, Academy of Agriculture, 71-460 Szczecin (Poland)

Veterinary Hygiene Research Station, 71-337 Szczecin (Poland)

Received April 20, 1979

\begin{abstract}
Przytulski T., D. Porzeczkowska: Genetic Markers of Resistance to Leptospirosis in Pigs of the Large White Polish Breed. Acta vet. Brno, 49, 1980: 237-244.

Data obtained from 1200 Large White pigs in two farms show that in pigs producing Am BB, Akp AB, Pra AB or BB, Tf AB there is a significantly lower incidence of leptospirosis than in pigs producing Am AB, Akp BB or BC, Pra AA and Tf BB phenotypes. A significantly lower incidence also appears in pigs heterozygous for $\mathrm{Hpx}$ as compared to homozygous and a higher incidence in homozygotes $\mathrm{Hpx} 1-1$ as compared to the other homozygous considered together. This result was confirmed by the relationship between these phenotypes and the level of leptospira antibodies as well as by the effect of selection in relation to polymorphic loci.
\end{abstract}

Leptospirosis, pigs, polymorphism, resistance, blood.

Leptospirosis in an important zoonotic disease. A large percentage of cases in domestic animals and wildlife animals was described by Zamora et al. (1975), Smith et al. (1976), Bizoń (1973), Š ebek et al. (1976), Š ebek and Rosický (1975), Mateew and Manew (1975), Shotts et al. (1975)

Livestock herds can be protected against leptospirosis by a combination of proper management and vaccination procedures. The other way to protect the herds against leptospirosis is by breeding resistant animals.

Pleško (1977) found that young Chinese hamsters (Cricetulus griseus) were susceptible to the infection with leptospirosis. However, the animals inoculated with the cultures of the strains of Ballum and Tarassovi serogrups recovered and appeared healthy.

The genetic resistance to leptospirosis in pigs of Large White breed has been described by Przytulski and Porzeczkowska (1980). The percentage of progeny with positive results from matings between resistant boars and sows was very small $(2.2 \%)$. On the other hand the percentage of progeny with positive results from matings between susceptible boars and sows was the highest $(67.1 \%)$.

The phenotypes of blood enzymes and proteins may be genetic markers of resistance or susceptibility to leptospirosis in animals. Only a few studies are available on the association of protein and enzyme polymorphism in blood with leptospirosis in animals. Hodges et al. (1976) analyzed relationship of haemoglobin phenotypes with leptospirosis in sheep and they found that sheep with $\mathrm{AB}$ type haemoglobin exhibited more marked following inoculation with L. pomona than those with haemoglobin types $\mathrm{A}$ or $\mathrm{B}$.

The relationships between phenotypes of enzyme and protein in blood serum and leptospirosis in pigs was described by Przytulski and Porzeczkowska (1976, 1979b, 1979c).

The aim of our investigation was to find differences in serological diagnosis of leptospirosis according to the phenotypes for blood serum protein and enzyme as well as the relationship between polymorphic systems and the level of leptospira antibodies. 


\section{Materials and Methods}

The number of animals used are presented in Table 1. Serum samples had been chosen from the diagnostic materials of the Veterinary Hygiene Research Station. The pigs were taken from two farms.

The phenotypes of blood serum amylase (Am), alkaline phosphatase (Akp), prealbumin (Pra), transferrin ( $\mathrm{Tf}$ ), haemopexin ( $\mathrm{Hpx}$ ) were determined by starch gel electrophoresis according to Hesselholt (1969) and Zagulska (1976).

The whole population was divided into two groups. Pigs with negative results to leptospirosis test were placed in group I, pigs with positive results formed group II.

The serological test method used microscope agglutination following the recommendations of the Experts Committee WHO (1967a, 1967b, 1972). Four to fourteen-day-old standard Leptospira cultures were used as an antigen: RGA (icterohaemorrhagiae), Moskva V (grippotyphosa), M-84 (sejroe), Perepelicin (tarassovi), Pomona (pomona).

The results were statistically analyzed by $\mathrm{Chi}$ square. The effect of selection in relation to polymorphic loci was determined according to Semenova (1976) and Semenova et al. (1976).

\section{Results}

\section{The frequencies of phenotype}

The numbers of animals of the particular polymorphic systems in the population are presented in Table 1 .

The distribution of proteins and enzyme phenotypes as well as the frequencies of alleles in two farms were similar.

Table 1

The frequencies of phenotypes in the groups of pigs

\begin{tabular}{|c|c|c|c|c|}
\hline \multicolumn{2}{|c|}{ Phenotypes } & Group I (-) & Group II (+) & Percentage $(t)$ \\
\hline $\begin{array}{l}\text { Amylase } \\
\mathbf{N}=1659 \\
\text { No. of animals }\end{array}$ & $\begin{array}{l}\mathrm{AA} \\
\mathbf{B B} \\
\mathbf{A B}\end{array}$ & $\begin{array}{l}18 \\
677 \\
154 \\
849\end{array}$ & $\begin{array}{r}23 \\
598 \\
189 \\
810\end{array}$ & $\begin{array}{l}56.1 \\
46.9 \\
55.1 \\
48.8\end{array}$ \\
\hline $\begin{array}{l}\text { Alkaline phosphatase } \\
\mathrm{N}=824 \\
\text { No. of animals }\end{array}$ & $\begin{array}{l}\mathbf{A B} \\
\mathbf{B B} \\
\mathbf{B C}\end{array}$ & $\begin{array}{r}52 \\
270 \\
49 \\
361\end{array}$ & $\begin{array}{r}21 \\
386 \\
56 \\
463\end{array}$ & $\begin{array}{l}33.3 \\
58.8 \\
53.3 \\
56.2\end{array}$ \\
\hline $\begin{array}{l}\text { Prealbumins } \\
\mathbf{N}=631 \\
\text { No. of animals }\end{array}$ & $\begin{array}{l}\mathrm{AA} \\
\mathrm{BB} \\
\mathbf{A B}\end{array}$ & $\begin{array}{r}105 \\
81 \\
229 \\
415\end{array}$ & $\begin{array}{r}81 \\
33 \\
102 \\
216\end{array}$ & $\begin{array}{l}43.5 \\
28.9 \\
30.8 \\
34.2\end{array}$ \\
\hline $\begin{array}{l}\text { Transferrins } \\
\mathbf{N}=1270 \\
\text { No. of animals }\end{array}$ & $\begin{array}{l}\mathrm{AA} \\
\mathrm{BB} \\
\mathrm{AB}\end{array}$ & $\begin{array}{r}62 \\
223 \\
239 \\
524\end{array}$ & $\begin{array}{r}99 \\
375 \\
272 \\
746\end{array}$ & $\begin{array}{l}61.5 \\
62.7 \\
53.2 \\
58.7\end{array}$ \\
\hline $\begin{array}{l}\text { Hemopexins } \\
\mathbf{N}=531 \\
\text { No. of animals }\end{array}$ & $\begin{array}{l}0-0 \\
0-1 \\
0-2 \\
0-3 \\
1-1 \\
1-2 \\
1-3 \\
2-2 \\
2-3 \\
3-3\end{array}$ & $\begin{array}{r}2 \\
6 \\
6 \\
2 \\
220 \\
14 \\
26 \\
31 \\
27 \\
31 \\
365\end{array}$ & $\begin{array}{r}\overline{4} \\
\overline{-} \\
147 \\
2 \\
3 \\
5 \\
-5 \\
55\end{array}$ & $\begin{array}{l}40.0 \\
\\
40.0 \\
12.5 \\
10.3 \\
13.9 \\
13.9 \\
31.3\end{array}$ \\
\hline
\end{tabular}


Table 2

Significance of differences in the groups studied

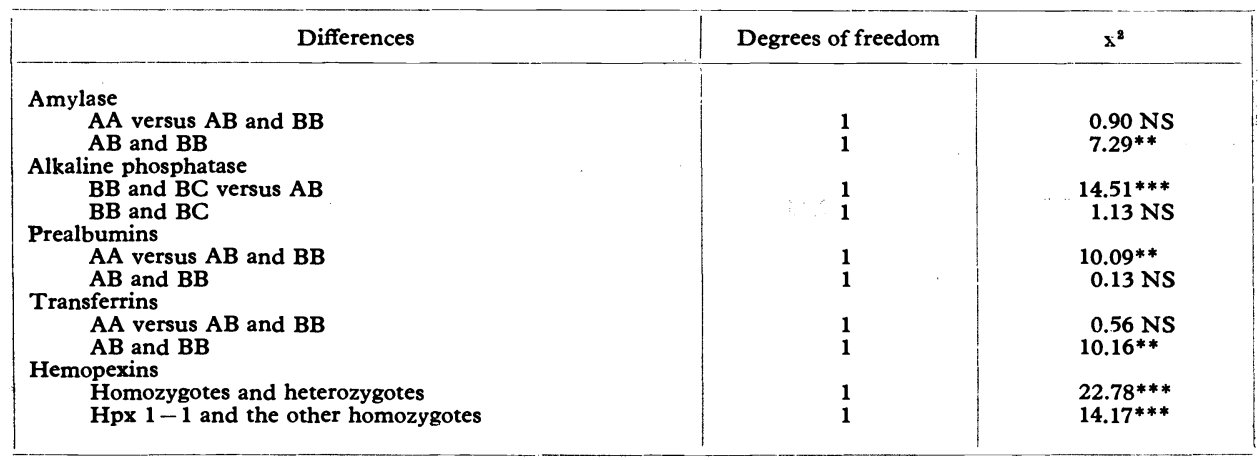

NS: Not significant

**: Significant at 0.01 level

***: Significant at 0.001 level

Percentage of animals with serologically negative and positive results in two farms also were similar.

The frequencies of protein and enzyme phenotypes in two groups are presented in Table 1 .

The phenotypes of Am, Pra, Tf, Hpx are determined by autosomal codominant alleles but the type of Akp inheritance was not analyzed.

In the population of pigs studied the animals possessing Am BB, Akp AB, Pra $A B$ or $B B$, Tf $A B$ phenotypes a highly significant lower $(P<0.01$ and $P<$ $<0.001$ ) incidence of leptospirosis infection than in pigs producing $A m A B$, Akp BB or BC, Pra AA and Tf BB phenotypes (Table 2).

The phenotypes of serum Hpx in the I group of pigs was observed. On the other hand, six phenotypes of Hpx were only observed in the II group of pigs. It must be noted, that the number of animals in the second group was small (166) in comparison to the first group (365) (Table 1).

The obtained values of $\mathrm{x}^{2}$ (Table 2 ) show a highly significant difference $(\boldsymbol{P}<$ $<0.001$ ) between frequencies of haterozygotes and homozygotes. In the pigs showing negative results of leptospirosis test there was stated a highly significant greater frequency of heterozygotes in comparison with the frequencies of homozygotes in pigs having positive results of leptospirosis test. Statistically highly significant difference $(P<0.001)$ was also stated for Hpx $1-1$ which occurred in II group with the frequency of $40.0 \%$ (Table 1) in comparison to the other homozygotes (Table 2). The pigs of Hpx 1-1 type had leptospirosis more frequently than the pigs with the other homozygotes compared together.

2. The effect of selection in relation to polymorphic loci

The phenotype of enzyme and protein controlled by two codominant alleles was only analyzed.

The effect of selection in relation to polymorphic loci are presented in Table 3. In group I pigs the frequencies of $\mathrm{Tf}+\mathrm{Am}(\mathrm{AA}+\mathrm{AA}, \mathrm{AB}+\mathrm{AA}), \operatorname{Pra}+\mathrm{Tf}$ $(A A+A A, B B+B B)$, Pra $+A m(B B+A B)$ combination of loci was lower and Tf + Am $(A A+B B, B B+A B), \operatorname{Pra}+\operatorname{Tf}(B B+A A, A B+A A), \operatorname{Pra}+A m(A B+A A)$ 
Table 3

The effect of selection in relation to polymorphic loci

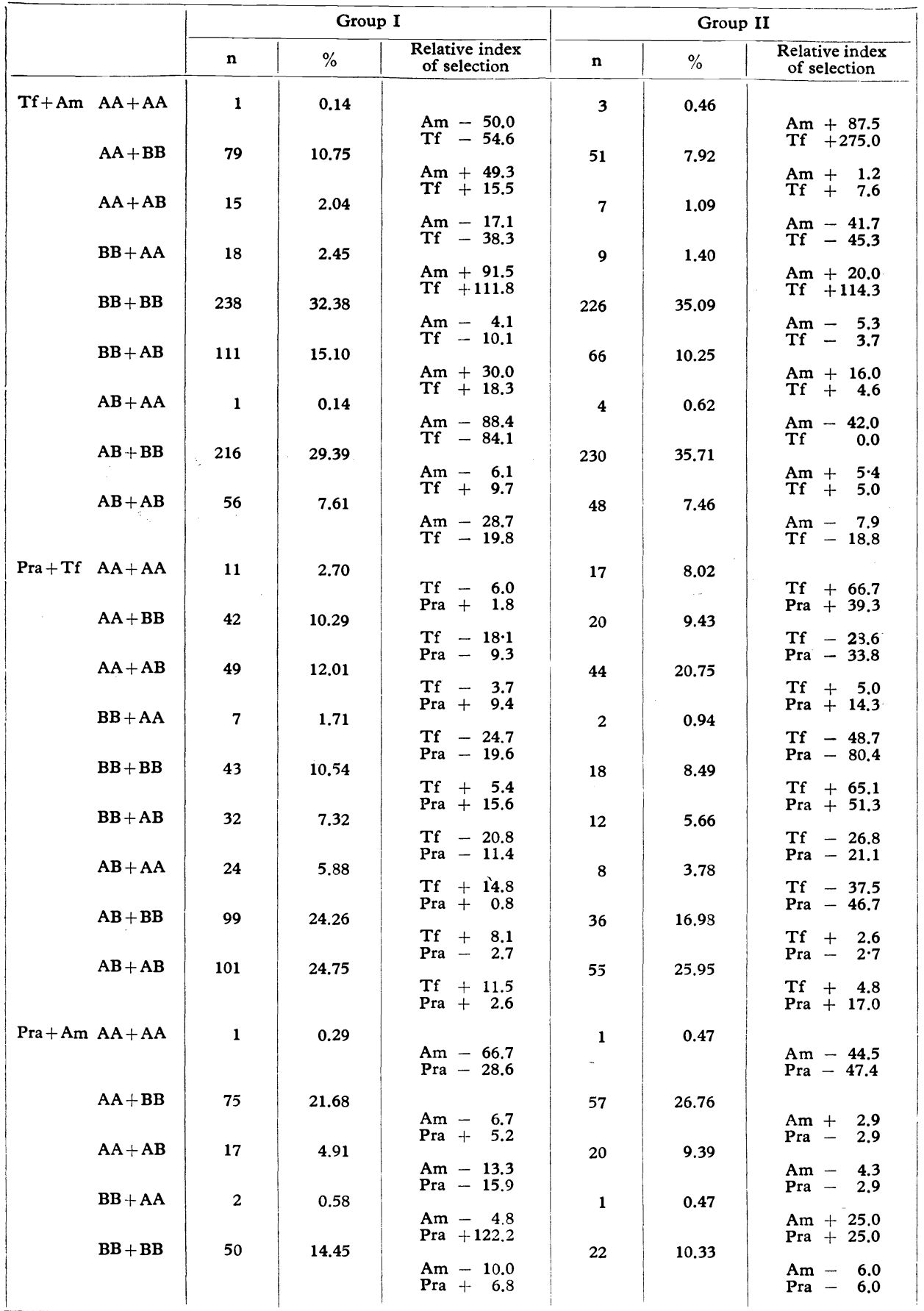


cont. Table 3

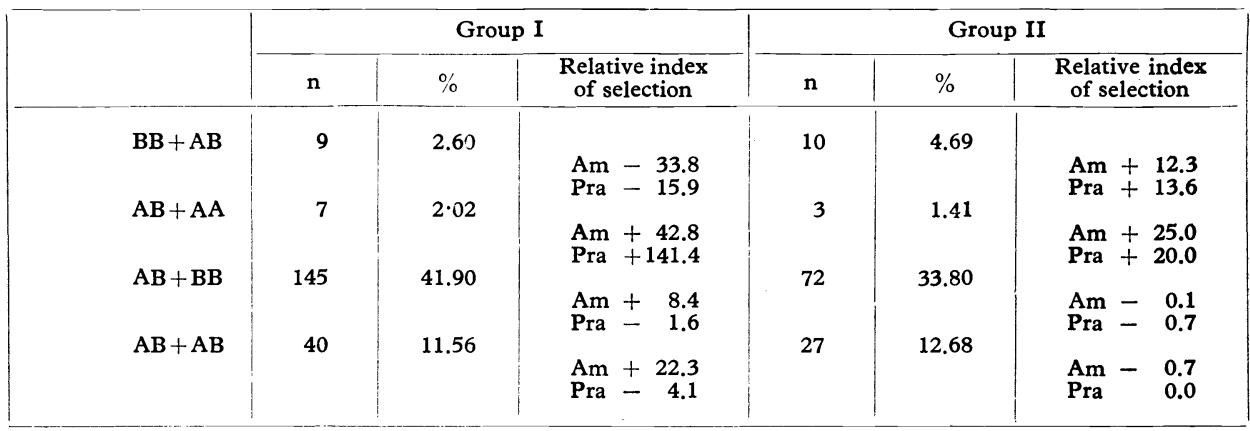

Table 4

The relationship between phenotypes and the level of leptospira antibodies

\begin{tabular}{|c|c|c|c|c|c|c|c|c|}
\hline \multicolumn{2}{|c|}{ Phenotypes } & $(-)$ & $\begin{array}{c}2 \\
1: 100- \\
-1: 200\end{array}$ & $\begin{array}{c}3 \\
1: 400- \\
-1: 1600\end{array}$ & $\begin{array}{c}4 \\
1: 3200- \\
-1: 12800\end{array}$ & Difference & DF & $x^{2}$ \\
\hline Am AA & $\begin{array}{l}\mathrm{n} \\
\%\end{array}$ & $\begin{array}{l}15 \\
2.17\end{array}$ & $\begin{array}{l}13 \\
2.39\end{array}$ & $\begin{array}{l}6 \\
4.48\end{array}$ & $\begin{array}{l}2 \\
2.22\end{array}$ & $\begin{array}{l}A A \text { versus } A B \\
\text { and } B B\end{array}$ & 3 & $1.54 \mathrm{NS}$ \\
\hline $\begin{array}{l}\text { Am BB } \\
\text { Am B }\end{array}$ & $\begin{array}{l}\mathbf{n} \\
\% \\
\mathbf{n} \\
\%\end{array}$ & $\begin{array}{l}545 \\
78.87 \\
131 \\
18.96\end{array}$ & $\begin{array}{l}409 \\
75.05 \\
123 \\
22.57\end{array}$ & $\begin{array}{l}99 \\
73.88 \\
29 \\
21.64\end{array}$ & $\begin{array}{l}60 \\
66.67 \\
28 \\
31.11\end{array}$ & $A B$ and $B B$ & 3 & $8.31^{*}$ \\
\hline & $\begin{array}{l}\mathrm{n} \\
\%\end{array}$ & $\begin{array}{l}42 \\
11.64\end{array}$ & $\stackrel{18}{5.36}$ & 2.60 & $\begin{array}{l}1 \\
2.00\end{array}$ & & & \\
\hline $\begin{array}{l}\text { Akp BB } \\
\text { Akp BC }\end{array}$ & $\begin{array}{l}\mathbf{n} \\
\% \\
\mathbf{n} \\
\%\end{array}$ & $\begin{array}{l}270 \\
74.79 \\
49 \\
13.57\end{array}$ & $\begin{array}{l}274 \\
81.55 \\
44 \\
13.09\end{array}$ & $\begin{array}{c}66 \\
85.71 \\
9 \\
11.69\end{array}$ & $\begin{array}{l}46 \\
92 \\
3 \\
6.00\end{array}$ & $\begin{array}{l}\text { BB and } B C \text { versus } \\
A B \\
B B \text { and } B C\end{array}$ & $\begin{array}{l}3 \\
3\end{array}$ & $\begin{array}{l}15.47^{* *} * \\
3.30 \mathrm{NS}\end{array}$ \\
\hline Pra AA & $\begin{array}{l}\mathrm{n} \\
\%\end{array}$ & $\begin{array}{r}105 \\
25.30\end{array}$ & $\begin{array}{l}34 \\
35.56\end{array}$ & $\begin{array}{l}28 \\
35.90\end{array}$ & $\begin{array}{l}19 \\
42.22\end{array}$ & & & \\
\hline $\begin{array}{l}\text { Pra BB } \\
\text { Pra AB }\end{array}$ & $\begin{array}{l}\mathrm{n} \\
\% \\
\mathrm{n} \\
\%\end{array}$ & $\begin{array}{l}81 \\
19.52 \\
229 \\
55.18\end{array}$ & $\begin{array}{l}13 \\
13.98 \\
46 \\
49.46\end{array}$ & $\begin{array}{l}14 \\
17.95 \\
36 \\
46.15\end{array}$ & $\begin{array}{l}6 \\
13.33 \\
20 \\
44.45\end{array}$ & $\begin{array}{l}A A \text { versus and } B B \\
A B \text { and } B B\end{array}$ & $\begin{array}{l}3 \\
3\end{array}$ & $\begin{array}{l}10.73 * \\
6.65 \mathrm{NS}\end{array}$ \\
\hline $\begin{array}{l}\text { Tf AA } \\
\text { Tf BB } \\
\text { Tf AB }\end{array}$ & $\begin{array}{c}\mathbf{n} \\
\% \\
\mathbf{n} \\
\% \\
\mathbf{n} \\
\%\end{array}$ & $\begin{array}{c}62 \\
11.83 \\
223 \\
42.56 \\
239 \\
45.61\end{array}$ & $\begin{array}{c}80 \\
14.54 \\
273 \\
49.64 \\
197 \\
35.82\end{array}$ & $\begin{array}{l}9 \\
7.96 \\
52 \\
46.02 \\
52 \\
46.02\end{array}$ & $\begin{array}{l}10 \\
12.05 \\
50 \\
60.24 \\
23 \\
27.71\end{array}$ & $\begin{array}{l}A A \text { versus and } B B \\
A B \text { and } B B\end{array}$ & $\begin{array}{l}3 \\
3\end{array}$ & $\begin{array}{l}0.56 \mathrm{NS} \\
10.16^{*}\end{array}$ \\
\hline
\end{tabular}

DF: Degrees of freedom

NS: Not significant

* : Significant at 0.05 level

** : Significant at 0.001 level

combination of loci was higher. On the other hand in group II pigs the frequencies of the first combination of loci was higher and the frequencies of the second combination of loci was lower.

\section{Relationships between the titre and the frequency of phenotypes and alleles}

Having taken as a criterion the agglutination titre, in the further stages of the investigation, the authors devided the animals into four groups: serologically negative (group 1), with low titre - from 1:100 to 1:200 (group 2), with medium 
titres - from $1: 400$ to $1: 1600$ (group 3) and with high titres - from $1: 3200$ to $1: 12800$ (group 4).

In the present study, the phenotypes and alleles of $\mathrm{Hpx}$ were not analyzed, because the number of animals with positive results was small (Table 1).

The characterization of the investigated groups and significance of difference between groups in the frequency of phenotypes and alleles is presented in Table 4.

With the presence of the Am AB, Akp BB or BC, Pra AA, Tf BB phenotypes the level of leptospira antibodies increased and it decreased with the presence of the Am BB, Akp AB, Pra AB or BB, Tf AB phenotypes $(P<0.05$ and $P<$ $<0.01)$.

\section{Discussion}

The results of the investigation show that Am, Akp, Pra, Tf and Hpx phenotypes and alleles may be to some extent a genetic marker of natural resistance or susceptibility to leptospirosis in pigs of the Large White breed.

Transferrin plays a vital and central role in iron metabolism and second important function, that of participating in th? body's defence mechanism against infections (Morgan 1974). The physiological function of blood serum Hpx indicated their main role in the processes connected with leptospirosis infection. The main function of hemopexins is ability to a binding of free heme as well as a removing of free heme from the blood vessels. In a study of experimental Leptospira serotype pomona infection in sheep, Hodges (1974) found that the severity of the resultant haemoglobinuria and anemia did not appear to be related to the number of leptospirae inoculated. In the acute form of leptospirosis (more often found in cattle), anemia, haemoglobinuria, icterus may be observed on autopsy (Diesch et al. 1976). In the accessible literature no information concerning relationship between the physiological function of hemopexins and their phenotypes has been found.

Such markers are of interest as possible criteria for detecting and selecting disease-resistant pigs.

The preliminary investigation also indicates the extremely important role which genetic typing of pigs could play as a supplementary measure in the control of leptospirosis. Genetic typing could be put to increased practical use if it were possible to develop a system of typing sows, boars and piglets to permit early elimination of animals which are genetically predisposed to infectious leptospirosis.

The associations are of two types. They may be (1) due to a gene with a pleiotropic action, that is, more than one phenotypic expression, or (2) due to true genetic linkage, that it, the presence of two different genes on the same chromosome (Payne 1973; Hutt, 1958, 1974, 1975).

The resistance to infectious disease is more likely to be polygenic than monogenic but the type of inheritance of leptospirosis resistance has been not known (Przytulski and Porzeczkowska 1980). This study shows that in pigs producing Am BB, Akp AB, Pra AB or BB, Tf $A B$ and heterozygotes of $\mathrm{Hpx}$ there is a significantly lower incidence of leptospirosis infection.

This result was confirmed by the relationships between protein and enzyme phenotypes and the level of leptospira antibodies. With the presence of the Am BB, Akp $A B$, Pra $A B$ od $B B$, Tf $A B$ phenotypes the level of leptospira antibodies decreased (Table 4). On the other hand, Przytulski and Porzeczkowska 
(1980) found that in resistant pigs the level of leptospira antibodies was low (from $1: 100$ to $1: 200$ ) and they suggest that the more antibodies the less resistant animal.

These results were also confirmed by the effect of selection in relation to polymorphic loci. This preliminary result indicated that a process of leptospira infection in pigs with these combinations of loci was different. In the population of Large White pigs studied these phenotypes of enzyme and protein may be a bar for leptospirosis infection.

According to many authors (Michna 1967; WHO, 1967a, 1967b) the reaction microscope agglutination with living antigens is sensitive and specific, as little as 1:100 titre being taken as an indicator of infection. In the population studied the level of leptospira antibodies in seroreagents was contained within the limits of titre from $1: 100$ to $1: 12800$.

It must be noted, that in case of germ carrying, as well as during the acute phase of the disease, the agglutination test may result in a low or negative reaction (Sullivan 1974).

Since leptospira antibodies remain in blood serum for months or years after infection, the serological test helps to identify both the animals in an acute form of infection and those with an chronic infection (Turner 1968, 1967; Sullivan 1974; Fig. 1).

A study carried out in Large White pigs, in which leptospirosis was clinically and bacteriologically observed, would confirm our work. The specific mechanism of Am, Akp, Pra, Tf, Hpx in the immune response and its role as a defence factor against infection of leptospira need further detailed investigations.

\section{Genetické markery resistence $k$ leptospiróze u prasat plemene velkého bílého polskẻho}

Údaje získané na 1200 prasatech plemene velké bílé ze dvou farem ukazují, že zvířata vylučující $\mathrm{Am} B \mathrm{~B}, \mathrm{Akp} A B$, Pra $\mathrm{AB}$ anebo $\mathrm{BB}$, Tf $\mathrm{AB}$ se vyznačuji signifikantně nižší incidencí leptospirózní infekce než prasata produkující Am AB, Akp BB anebo BC, Pra AA a Tf BB fenotypy. Signifikantně nižší incidence nemoci byla též zaznamenána u prasat heterozygotních pro Hpx než u zvírat homozygotních a vyšší u homozygotů $\mathrm{Hpx} 1-1$ než u všech ostatních homozygotů. Tento výsledek byl potvrzen i vztahem těchto fenotypů $k$ hladině protilátek a také vlivem selekce ve vztahu $\mathrm{k}$ polymorfním lokusům.

\section{Генетические маркеры сопротивляемости к лентоспирозу поросят крупной белой польской породы}

Полученные на двух свинофермах с исследуемыми 1200 поросятами крупной белой породы данные свидетельствуют о том, что животные с выявлением Ам, ВВ, Акр АВ, Пра АВ или ББ, ТАВ отличаются явно более низкой инциденцией дептоспирозной инфекции по сравнению с поросятами, продуцирующими Ам AB, Акр ВB или ВC, Пра АА и ТВВ фенотипы. Фвно более низкая инциденция болезни отмечалась у поросят гетерозиготных для $\mathrm{Hpx}$ чем у животных гомозиготных и более высокая - у зиготов Hpx 1-1 чем у всех остальных гомозиготов. Данный результат был также подтвержден отношением данных фенотипов к уровню антивеществ и влиянием селекции по отношению к полиморфным локусам. 


\section{References}

BIZOŃ, A.: Med. Wet., 29, 1973: 701.

DIESCH, S. L. - GLOSSER, J. W. - HANSON, L. E. - MORTER, R. L. - SMITH R. E. - STOENNER, H. G.: Leptospirosis of domestic animals. Agric. Inform. No. 394, 1976: Agric. Res. Ser., US Dep. Agric.

HESSELHOLT, M.: Serum protein polymorphism in swine. Copenhagen, 1969. Munksgaard.

HODGES, R. T.: Some observations on experimental Leptospira serotype pomona infection in sheep. N. Z. vet. J., 22, 1974: 151.

HODGES, R. T. - MILLAR, K. R. - REVFEIM, K. J. A.: The effects of Leptospira serotype pomona in sheep of different haemoglobin types. N. Z. vet. J., 24, 1976: 163.

HUTT, F. B.: Genetic resistance to disease in domestic animals. Ithaca, New York, 1958, Cornell University Press.

HUTT, F. B.: Genetic indicators of resistance to disease in domestic animals. 1st World Congr. Genet. Applied Livest. Prod., Madrid, 7-11 October, 1974: 179.

HUTT, F. B.: Genetyczna oporność zwierzat domowych na choroby. Zesz. Probl. Post. Nauk Rol., 163, 1975: 149.

MATEEW, D. - MENEW, Chr.: Untersuchungen über Leptospiren in Bulgarien. Leptospira and Spirochaeta Symp., Bucharest, 1975: 167.

MICHNA, S. W.: Animal leptospirosis in the British Isles- a serological survey. Vet. Rec., 80, 1967: 394.

MORGAN, E. H.: Transferrin and transferrin iron. In: Iron in Biochemistry and Medicine. Jacobs and Warwood, 1974, Academic Press London and New York, 1974: p. 29.

PAYNE, L. N.: Genetic and control of avian diseases. Avian Pathol., 4, 1973: 237.

PLEŠKO, I.: Experimental leptospirosis in Chinese hamsters. Biologia (Bratislava), 32, 1977 : 169.

PRZYTULSKI, T. - PORZECZKOWSKA, D.: Polymorphism of blood serum amylase and leptospirosis of pigs of Large White Polish breed. Theoret. Applied Genet., 48, 1976: 237.

PRZYTULSKI, T. - PORZECZKOWSKA, D.: Studies on genetic resistance to leptospirosis in pigs. Br. vet. J., 136, 1980: 25.

PRZYTULSKI, T. - PORZECZKOWSKA, D.: Polymorphism of blood serum amylase and transferrin and leptospirosis in Large White Polish pigs. Br. vet. J., 135, 1979b: 103.

PRZYTULSKI, T. - PORZECZKOWSKA, D.: Serum protein and enzyme polymorphism and leptospirosis of pigs of Large White Polish breed. Ann. Genet. Sel. Anim., 11, 1979c: 121.

SEMENOVA, E. I.: Amylase and ceruloplasmin gene sets selection in cattle and methods of its determination. Cit. Genet., 3, 1976: 229.

SEMENOVA, E. I. - BLIZNICHENKO, M. A. - RIJ, T. B.: Effect of interrelated compensation within different systems of cattle blood polymorphous protein. Cit. Genet., 1, 1976: 26.

SMITH, R. E. - WILLIAMS, I. A. - KINGSBURY, E. T.: Serologic evidence of equine leptospirosis in the Northeast United States. Cornell Vet., 66, 1976: 105.

SHOTTS, E. B. - ANDREWS, Ch. L. - HARVEY, T. W.: Leptospirosis in selected wild mammals of the Florida Panhandle and Southwestern Georgia. J. Amer. Vet. Med. Assoc., 167, 1975: 587 .

ŠEBEK, Z. - ROSICKÝ, B.: Die Verbreitung und biotische Struktur der Leptospiroseherde in einigen europäischen Staaten. Zbl. Bakt. Hyg., I. Abt. Orig., A 233, 1975: 380.

ŠEBEK, Z. - WALLNER, H. - SIXL, W. - KAASERER, G. - VALOVÁ, M.: Leptospiral antibodies in domestic animals in Tirol., 23, 1976: 15.

SULLIVAN, N. D.: Leptospirosis in animals and man, Aust. Vet. J., 50, 1974: 216.

TURNER, L. H.: Leptospirosis I. Trans. R. Soc. Trop. Med. Hyg., 61, 1967: 842.

TURNER, L. H.: Leptospirosis II. Trans. R. Soc. Trop. Med. Hyg., 62, 1968: 880.

WHO Expert Committee (Joint FAO) on Zoonoses: Third Report. Technical Report Series. World Health Organ., 1967a: 387.

WHO Expert Group: Technical Report Series. World Health Organ., 1967b: 380.

WHO Expert Group: WHO Bulletin, 47, 1972: 113.

ZAGULSKA, A.: Elektroforetyczny polimorfizm fosfatazy alkalicznej u świń rasy zlotnickiej pstrej. VI Zjazd Pol. Tow. Genet., Białystok, 1976.

ZAMORA, J. - KRUZE, J. - RIEDEMANN, S.: Leptospirosis de los Animales Domésticos en el Sur de Chile. Estudio Serológico. Zbl. Vet. Med. B., 22, 1975: 544. 